\title{
Molecular and Cellular Characteristics of the Colonic Pseudo-obstruction in Patients With Intractable Constipation
}

\author{
Yoon Suh Do, ${ }^{1}$ Seung-Jae Myung, ${ }^{1}$ Sun-Young Kwak, ${ }^{2}$ Soohan Cho, ${ }^{2}$ Enoch Lee, ${ }^{2}$ Min Jeong Song, ${ }^{3}$ Chang Sik Yu, ${ }^{4}$ \\ Yong Sik Yoon, ${ }^{4}$ and Hye Kyung Lee ${ }^{2 *}$ \\ ${ }^{1}$ Department of Gastroenterology, Asan Digestive Disease Research Institute, Departments of ${ }^{2}$ Pharmacology, ${ }^{3}$ Pathology, and ${ }^{4}$ Colon and Rectal \\ Surgery, University of Ulsan College of Medicine, Asan Medical Center, Seoul, Korea
}

\begin{abstract}
Background/Aims
Chronic intestinal pseudo-obstruction (CIPO) is a disorder characterized by recurrent symptoms suggestive of obstruction such as abdominal pain, proximal distension with extremely suppressed motility in the absence of lumen-occluding lesion, whose etiology/pathophysiology is poorly understood. In this study we investigated a functionally obstructive lesion that could underlie symptoms of CIPO.
\end{abstract}

\section{Methods}

We studied colons surgically removed from 13 patients exhibiting clinical/pathological features of pseudo-obstruction but were unresponsive to standard medical treatments. The colons were characterized morphologically, functionally and molecularly, which were compared between regions and to 28 region-matched controls obtained from colon cancer patients.

\section{Results}

The colons with pseudo-obstruction exhibited persistent luminal distension proximally, where the smooth muscle was hypertrophied with changes in the cell phenotypes. Distinct luminal narrowing was observed near the distal end of the dilated region, close to the splenic flexure, previously referred to as the "transition zone (TZ)" between the dilated and non-dilated loops. Circular muscles from the TZ responded less to depolarization and cholinergic stimulation, which was associated with downregulation of L-type calcium channel expression. Smooth muscle contractile protein was also downregulated. Myenteric ganglia and neuronal nitric oxide synthase (nNOS) positive cells were deficient, more severely in the TZ region. Interstitial cells of Cajal was relatively less affected.

Received: March 18, 2015 Revised: June 11, 2015 Accepted: July 6, 2015

(c) This is an Open Access article distributed under the terms of the Creative Commons Attribution Non-Commercial License (http://creativecommons. org/licenses/by-nc/4.0) which permits unrestricted non-commercial use, distribution, and reproduction in any medium, provided the original work is properly cited.

\section{${ }^{*}$ Correspondence: Hye Kyung Lee, PhD}

Department of Pharmacology, University of Ulsan College of Medicine, 88, Olympic-ro 43-gil, Songpa-gu, Seoul 05505, Korea Tel: +82-2-3010-4280, Fax: +82-2-3010-2941, E-mail: kyung@amc.seoul.kr

Financial support: This research was supported by the Basic Science Research Program through the National Research Foundation of Korea (NRF) Conflicts of interest: None. funded by the Ministry of Science, ICT \& Future Planning (2013R1A1A2008753).

Author contributions: Yoon Suh Do, study conception, analysis and interpretation of data, critical revision for important intellectual content, and administrative and technical support; Seung-Jae Myung, study conception, critical revision for important intellectual content, and approval of the final version of the manuscript; Sun-Young Kwak, Soohan Cho, and Enoch Lee, collection, assembly and analysis of data, and technical support; Min Jeong Song, assembly, analysis and interpretation of data; Chang Sik Yu and Yong Sik Yoon, approval of the final version of the manuscript and material support; Hye Kyung Lee, study conception and design, analysis and interpretation of data, drafting and revising the manuscript, and obtained funding. 


\section{Conclusions}

The TZ may be the principal site of functional obstruction, leading to proximal distension and smooth muscle hypertrophy, in which partial nNOS depletion could play a key role. The neuromuscular abnormalities probably synergistically contributed to the extremely suppressed motility observed in the colonic pseudo-obstruction.

(J Neurogastroenterol Motil 2015;21:560-570)

\section{Key Words}

Colon; Hypoganglionosis; Intestinal Pseudo-obstruction; Nitric oxide; Smooth muscle

\section{Introduction}

Chronic intestinal pseudo-obstruction (CIPO) is a disabling intestinal disorder characterized by recurrent symptoms suggestive of intestinal obstruction such as abdominal pain, proximal distension with extremely suppressed motility in the absence of lumen-occluding lesion. ${ }^{1,2}$ While CIPO could occur secondary to various pathological conditions, the etiology of most primary CIPO is idiopathic with undefined pathophysiology. Although CIPO conventionally referred to pediatric cases that generally involved the small bowel, ${ }^{3,4}$ primary CIPO has also been reported in adults, ${ }^{5-11}$ where over $60 \%$ of primary cases involved the large bowel. ${ }^{11}$ Relative to the pediatric type, adult type has not been extensively studied.

Previously, we observed a subset of adult patients with chronic intractable constipation exhibited clinical/pathological features of CIPO in the colon. ${ }^{9}$ Some of these patients with colonic pseudo-obstruction (CPO) underwent surgical treatment because their symptoms did not improve by conventional medical treatments and frequent hospitalizations were required to drain the contents, which resulted in poor quality of life. In the colon of these patients, distinct luminal narrowing was apparent in the intersection of proximal dilated and distal non-dilated loop (referred to as the transition zone [TZ]). ${ }^{6-10}$ Consistent observations of the $\mathrm{TZ}$ by us ${ }^{9}$ and others ${ }^{6-8,10}$ lead us to hypothesize that the $\mathrm{TZ}$ may be the site of functional obstruction and involved in the pathogenesis/pathophysiology of CPO. Given that gastrointestinal (GI) motility depends on the coordinated activity of 3 major cell types, ie, smooth muscle, interstitial cells of Cajal (ICC) and enteric neurons, we studied these cells in the TZ region using morphological, functional and molecular techniques,

Table 1. Clinical Characteristics

\begin{tabular}{|c|c|c|c|c|c|c|c|c|c|c|}
\hline \multirow[b]{2}{*}{$\begin{array}{l}\text { Patient } \\
\text { No. }\end{array}$} & \multirow[b]{2}{*}{ Sex } & \multirow[b]{2}{*}{$\begin{array}{l}\text { Age at } \\
\text { surgery }\end{array}$} & \multicolumn{2}{|c|}{ Defecation frequency } & \multirow[b]{2}{*}{ RAIR } & \multirow[b]{2}{*}{$\begin{array}{l}\text { Performed } \\
\text { operation }\end{array}$} & \multicolumn{3}{|c|}{ Sample location } & \multirow{2}{*}{$\begin{array}{c}\text { CT finding } \\
\text { TZ }\end{array}$} \\
\hline & & & $\begin{array}{l}\text { Before surgery } \\
\text { (times/wk) }\end{array}$ & $\begin{array}{c}\text { At } 1 \text { year } \\
\text { post-operation } \\
\text { (times/day) }\end{array}$ & & & $\begin{array}{c}\text { Proximal } \\
\text { dilated }\end{array}$ & $\mathrm{TZ}$ & $\begin{array}{l}\text { Non- } \\
\text { dilated }\end{array}$ & \\
\hline 1 & $\mathrm{~F}$ & 28 & 0.5 & 10 & Present & $\mathrm{TC}$ & $\mathrm{T} / \mathrm{C}$ & $\mathrm{D} / \mathrm{C}$ & $\mathrm{S} / \mathrm{C}$ & $\mathrm{D} / \mathrm{C}$ \\
\hline 2 & M & 28 & 0.7 & 3 & Present & $\mathrm{TC}$ & $\mathrm{T} / \mathrm{C}$ & $\mathrm{D} / \mathrm{C}$ & $\mathrm{S} / \mathrm{C}$ & $\mathrm{D} / \mathrm{C}$ \\
\hline 3 & M & 40 & 0.7 & 2 & Present & $\mathrm{TC}$ & $\mathrm{T} / \mathrm{C}$ & $\mathrm{D} / \mathrm{C}$ & $\mathrm{S} / \mathrm{C}$ & $\mathrm{D} / \mathrm{C}$ \\
\hline 4 & $\mathrm{~F}$ & 31 & 0.7 & 2 & Present & $\mathrm{TC}$ & $\mathrm{T} / \mathrm{C}$ & $\mathrm{D} / \mathrm{C}$ & $\mathrm{S} / \mathrm{C}$ & $\mathrm{D} / \mathrm{C}$ \\
\hline 5 & M & 35 & 1.4 & $1-2$ & Present & $\mathrm{TC}$ & $\mathrm{T} / \mathrm{C}$ & $\mathrm{D} / \mathrm{C}$ & $\mathrm{S} / \mathrm{C}$ & $\mathrm{D} / \mathrm{C}$ \\
\hline 6 & $\mathrm{~F}$ & 28 & 0.7 & 7 & Present & $\mathrm{TC}$ & $\mathrm{A} / \mathrm{C}$ & $\mathrm{D} / \mathrm{C}$ & $\mathrm{S} / \mathrm{C}$ & $\mathrm{D} / \mathrm{C}$ \\
\hline 7 & M & 28 & 0.7 & 2 & Present & $\mathrm{TC}$ & $\mathrm{A} / \mathrm{C}$ & $\mathrm{D} / \mathrm{C}$ & $\mathrm{S} / \mathrm{C}$ & $\mathrm{D} / \mathrm{C}$ \\
\hline 8 & M & 50 & 1.4 & 6 & Present & $\mathrm{TC}$ & $\mathrm{A} / \mathrm{C}$ & $\mathrm{D} / \mathrm{C}$ & $\mathrm{S} / \mathrm{C}$ & $\mathrm{D} / \mathrm{C}$ \\
\hline 9 & $\mathrm{~F}$ & 34 & 1.0 & $2-3$ & Present & $\mathrm{TC}$ & $\mathrm{A} / \mathrm{C}$ & $\mathrm{D} / \mathrm{C}$ & $\mathrm{S} / \mathrm{C}$ & $\mathrm{D} / \mathrm{C}$ \\
\hline 10 & $\mathrm{~F}$ & 40 & 0.3 & 1 & Present & $\mathrm{TC}$ & $\mathrm{A} / \mathrm{C}$ & $\mathrm{D} / \mathrm{C}$ & $\mathrm{S} / \mathrm{C}$ & $\mathrm{D} / \mathrm{C}$ \\
\hline 11 & $\mathrm{~F}$ & 45 & 1.0 & 5 & Present & $\mathrm{TC}$ & $\mathrm{T} / \mathrm{C}$ & $\mathrm{D} / \mathrm{C}$ & $\mathrm{S} / \mathrm{C}$ & $\mathrm{D} / \mathrm{C}$ \\
\hline 12 & $\mathrm{~F}$ & 38 & 1.4 & 2 & Present & $\mathrm{TC}$ & $\mathrm{A} / \mathrm{C}$ & $\mathrm{D} / \mathrm{C}$ & $\mathrm{S} / \mathrm{C}$ & $\mathrm{D} / \mathrm{C}$ \\
\hline 13 & M & 37 & 1.4 & $2-3$ & Present & TC & $\mathrm{T} / \mathrm{C}$ & $\mathrm{D} / \mathrm{C}$ & $\mathrm{S} / \mathrm{C}$ & $\mathrm{D} / \mathrm{C}$ \\
\hline
\end{tabular}

RAIR, rectoanal inhibitory reflexes; $\mathrm{M}$, male; F, female; TC, total colectomy; $\mathrm{A} / \mathrm{C}$, ascending colon; $\mathrm{T} / \mathrm{C}$, transverse colon; $\mathrm{D} / \mathrm{C}$, descending colon; $\mathrm{S} / \mathrm{C}$, sigmoid colon. 
which were compared with other regions of the CPO colons and to region-matched controls obtained from colon cancer cases.

\section{Materials and Methods}

This study was performed according to the institutional review board guidelines of Asan medical center, Seoul, Korea.

\section{Patients}

The specimens of colons were obtained from a total of $13 \mathrm{pa}-$ tients ( 6 men and 7 women; mean age $\pm \mathrm{SD}, 36 \pm 7$ years) (Table 1 ) with a long-standing history ( $\leq 15$ years; $5 \pm 4$ years) of intractable constipation with severe dilation of the proximal colon (Fig. 1A). Symptoms suggestive of obstruction such as abdominal pain, extremely suppressed colonic motility, and severe proximal distension persisted in the absence of clear organic causes on endoscopic, surgical and radiological examinations. Colonic transit time was studied using radiopaque markers and was markedly prolonged to as long as 80 hours. Extensive dilated bowel loops or an air-fluid level was evident without occlusive fixed organic lesions on endoscopic and radiological examinations. In anorectal manometric findings, rectoanal inhibitory reflexes (RAIR) were clearly present in all 13 patients, which allowed us to rule out the possibility of Hirschsprung's disease. Patients with secondary causes of constipation such as diabetes mellitus or paraplegia, and motor dysfunction in the upper gastrointestinal tract were also excluded from this study.

All conventional medical treatments failed to improve pa-
A

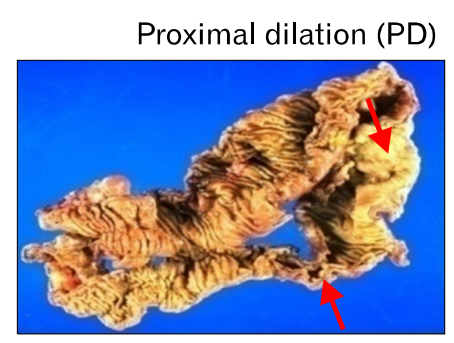

Transition zone (TZ)

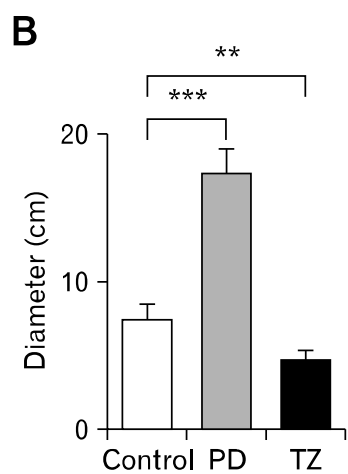

Control PD TZ
Figure 1. Gross morphology of 2 distinct regions observed. (A) Severely distended proximal colon (proximal dilation [PD]) was accompanied by a narrowed transition zone (TZ) located at the intersection of the dilated PD and distal non-dilated colon. (B) External luminal diameter of the PD was approximately 3 times larger than the TZ. ${ }^{* *} P<0.01,{ }^{* * *} P<0.001$. tients' symptoms, and frequent hospitalizations were needed to drain the impacted stool and relieve the symptoms, which left surgical treatment as the only remaining alternative. The most effective surgical treatment for medically intractable constipation has been total colectomy with ileorectal anastomosis. ${ }^{10,12-14}$ In 5 patients (20 samples across different regions) where the specimens were prospectively collected over an approximately 5 -year period, a series of morphological, functional and molecular studies were performed in addition to routine histopathology. Due to the infrequency of extreme cases that require surgery, colons from 8 patients (24 samples across different regions) were retrospectively studied, of which the histopathological and morphometric characteristics were assessed.

\section{Controls}

The specimens of control colons were obtained from a total of 28 patients ( 15 men and 13 women; $58 \pm 13$ years) who underwent partial colectomy for non-obstructive early stage colon cancer, where 15 cases ( 45 samples across different regions) received a series of morphological, functional and molecular assessments and 13 cases were retrospectively studied.

\section{Tissue Preparation}

Immediately after colectomy surgery, colonic tissue segments were carefully isolated from different regions of the colon (ascending, transverse, descending, sigmoid colon) and transferred to Krebs-Ringer (K-R) buffer solution that had been saturated with $95 \% \mathrm{O}_{2} / 5 \% \mathrm{CO}_{2}$. The colonic tissues were then prepared for functional and molecular studies as well as morphological evaluation. From the controls, the most proximal end of the region-matched colonic tissues was isolated and used.

\section{Hematoxylin and Eosin Staining}

Standard histopathology was performed on the hematoxylin and eosin (H\&E)-stained samples, from which the morphometric characteristics were assessed. Tissue segments were fixed in $4 \%$ paraformaldehyde, embedded in paraffin blocks, and $5-\mu \mathrm{m}$ thick sections were cut and placed on glass slides for routine $\mathrm{H} \& \mathrm{E}$ staining.

Cross-sectional muscle thickness was measured under the microscope in the H\&E-stained samples. The number of nuclei in the H\&E-stained section was counted under the microscope to estimate the cell number, from which the cell density per $100 \mu \mathrm{m}$ cross section was estimated. 


\section{Protein to DNA Content Ratio}

To evaluate changes in cell size, the protein to DNA content ratio was determined. Total cellular protein was measured using the Bradford Protein Assay system (Bio-Rad Laboratories, Hercules, CA, USA). Genomic DNA was isolated using a phenol chloroform isopropanol extraction and the DNA concentration was measured using a spectrophotometer (Nano Drop Technologies, Wilmington, DE, USA). The protein to DNA content ratio was calculated from the $\mathrm{CPO}$ colons and compared to the region-matched controls.

\section{Isometric Tension Measurement}

A set of functional, molecular and immunohistochemical studies were performed in series on the colons obtained from 5 CPO patients (No.1-5 in Table 1). Smooth muscle contractility was evaluated in a conventional organ bath by measuring isometric tension. Strips of circular muscles without mucosa were cut parallel to the circular fibers in the K-R buffer solution and mounted in a $30 \mathrm{~mL}$ organ bath containing $\mathrm{K}-\mathrm{R}$ buffer saturated with $95 \% \mathrm{O}_{2} / 5 \% \mathrm{CO}_{2}$ at $37^{\circ} \mathrm{C}$. A resting tension of 1 gram was applied and equilibrated for at least 1 hour. Basal contractility and contractile responses developed to depolarizing potassium chloride $(\mathrm{KCl})$ and the cholinergic receptor agonist carbachol $(\mathrm{CCh})$ were evaluated. The contractile force was recorded on a physiograph and digitized. Data were normalized to the wet tissue weight and compared to the region-matched controls.

\section{Quantitative Polymerase Chain Reaction}

The expression levels of the genes encoding the proteins in- volved in smooth muscle contraction, L-type calcium $\left(\mathrm{Ca}^{2+}\right)$ channel (pore subunit $\alpha_{1} \mathrm{C}$ ), muscarinic M3 receptor, and contractile proteins smooth muscle alpha-actin (SMAA) and smooth muscle myosin heavy chain (SMMHC) isoform SM2 were evaluated using real time PCR. Total RNA was extracted using the TRIzol reagent (Invitrogen, Carlsbad, CA, USA) and cDNA was prepared using the oligo dT primer and Avian Myeloblastosis Virus reverse transcriptase (Promega, Madison, WI, USA). Quantitative real-time PCR was performed using cDNAs, each set of gene-specific primers (Table 2) and the Sybr Green Master Mix (Applied Biosystems, Foster City, CA, USA) on the ABI PRISM 7000 Sequencer (Applied Biosystems) according to the manufacturer's protocol. Quantitative PCR conditions included denaturation at $95^{\circ} \mathrm{C}$ for 10 minutes, followed by 40 cycles at $95^{\circ} \mathrm{C}$ for 15 seconds and annealing at $60^{\circ} \mathrm{C}$ for 1 minute. After quantitative PCR, specificity was confirmed by running the PCR products on $2 \%$ agarose gels. Raw fluorescence data $\left(\mathrm{C}_{\mathrm{T}}\right)$ was exported from the ABI PRISM software (version 1.2) and the relative quantities of each gene were calculated using the comparative $\mathrm{C}_{\mathrm{T}}$ method. ${ }^{15}$ The relative values of each gene were normalized to glyceraldehyde-3-phosphate dehydrogenase (GAPDH).

\section{Immunohistochemistry}

Immunohistochemical studies were performed on the major excitatory and inhibitory neurotransmitter-containing cells and ICC. Tissue segments were fixed in $4 \%$ paraformaldehyde and dehydrated in graded sucrose solutions (10-30\%). The tissues were then embedded in Tissue Tek OCT compound (Sakura Finetek, Torrance, CA, USA) and frozen in liquid nitrogen. Cryostat sections were cut to $20 \mu \mathrm{m}$, which were then pre-in-

Table 2. Primer Sets Used

\begin{tabular}{|c|c|c|c|c|}
\hline Gene product & $\begin{array}{l}\text { GenBank accession no. } \\
\text { (NCBI) }\end{array}$ & Primer Sequences $\left(5^{\prime} \rightarrow 3^{\prime}\right)$ & Length & Product size (bp) \\
\hline \multirow[t]{2}{*}{ GAPDH } & \multirow[t]{2}{*}{ NM_002046 } & F: TCCTGCACCACCAACTGCTTAGC & 23 & \multirow[t]{2}{*}{110} \\
\hline & & R: GTCTTCTGGGTGGCAGTGATGG & 22 & \\
\hline \multirow[t]{2}{*}{$\alpha 1 \mathrm{C}(\mathrm{CACNA} 1 \mathrm{C})$} & \multirow[t]{2}{*}{ NM_000719 } & F: GGCTACCTGGATTGGATCACTC & 22 & \multirow[t]{2}{*}{61} \\
\hline & & R: TGCCTTCGTCCTCATTCTCAG & 21 & \\
\hline \multirow[t]{2}{*}{ M3 (CHRM3) } & \multirow[t]{2}{*}{ NM_000740 } & F: GTCACTCATTTCGGCAGCTACA & 20 & \multirow[t]{2}{*}{51} \\
\hline & & R: GGAGAAATTGCCAGCTGCTC & 20 & \\
\hline \multirow[t]{2}{*}{ SM actin (ACTA2) } & \multirow[t]{2}{*}{ ВC093052 } & F: GCATCСТCATCСТСССТTGAGAAG & 24 & \multirow[t]{2}{*}{140} \\
\hline & & R: GTTTCATGGATGCCAGCAGACTCC & 24 & \\
\hline \multirow[t]{2}{*}{ SMMHC (MYH11) } & \multirow[t]{2}{*}{ AY520817 } & F: CAGGAAACTTCGCAGTGATGCACC & 24 & \multirow[t]{2}{*}{114} \\
\hline & & R: CGTTTCCTCCTCAGAACCATCTGC & 24 & \\
\hline
\end{tabular}

GAPDH, glyceraldehyde-3-phosphate dehydrogenase; $\alpha 1 \mathrm{C}$, pore subunit of L-type $\mathrm{Ca}^{2+}$ channel; M3, muscarinic type 3 receptor; SM, smooth muscle; SMMHC, smooth muscle myosin heavy chain. 
cubated in $1 \%$ bovine serum albumin for 1 hour to reduce non-specific binding and incubated at $4^{\circ} \mathrm{C}$ overnight with antibodies against neuronal nitric oxide synthase (nNOS) (1:500 dilution; BD Transduction Laboratories, San Jose, CA, USA), vasoactive intestinal peptide (VIP) (1:400 dilution; Millipore, Billerica, MA, USA), vesicular acetylcholine transporter (vAChT) (1:200 dilution; Phoenix Pharmaceuticals, Burlingame, CA, USA) and substance P (SP) (1:400 dilution; Millipore). To detect ICC, tissues were incubated with anti-human c-kit antibody (1:500 dilution; Dakocytomation, Cambridge, MA, USA). Immunoreactivity was detected using fluorescein isothiocyanate (FITC)-conjugated IgG (1:200 dilution; Invitrogen-Molecular probes). Tissues were examined using a TCS-SPII confocal microscope (Leica Microsystems, Heidelberg, Germany) with an FITC-appropriate excitation wavelength (488 nm).

\section{Drugs}

Carbachol and reagents were obtained from Sigma-Aldrich (St Louis, MO, USA) unless specified otherwise. Carbachol was dissolved in distilled $\mathrm{H}_{2} \mathrm{O}$ and prepared immediately before use.

\section{Statistical Methods}

The unpaired Student's $t$ test or ANOVA was employed to assess data and differences were considered significant when $P<$ 0.05. SPSS software (version 21.0; SPSS Inc, Chicago, IL, USA) was used.

\section{Results}

\section{Clinical Description}

A total of 13 patients who were being treated at our institution and underwent surgical treatment were enrolled in this study. The diagnosis of pseudo-obstruction was made on the basis of clinical/radiological/manometric findings (see Patients in Methods). The patients unresponsive to conventional medical treatments underwent total colectomy with ileorectal anastomosis, which markedly improved defecation frequency (Table 1) and relieved abdominal pain and distension. Final pathological diagnosis was hypoganglionosis. There were no serious early or late postoperative complications, and all 13 patients were satisfied with the results of their surgeries.

\section{Morphometric Analysis}

The lumen of the proximal colon was significantly dilated (ie, proximal dilation [PD]) in the $\mathrm{CPO}$ colons (most profoundly in transverse colon) with an external diameter that increased by 2.3 times in comparison with region-matched controls $(P<0.001$, Fig. 1B). A narrowing of the lumen was observed near the distal end of the PD region, usually around the splenic flexure or upper
A

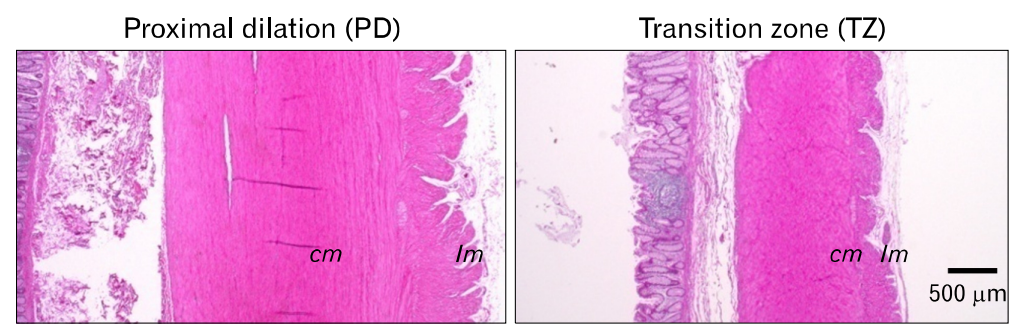

B

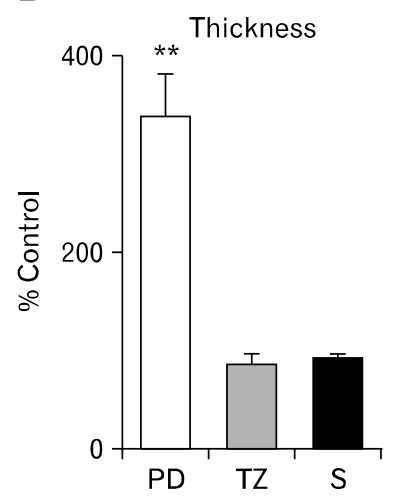

C

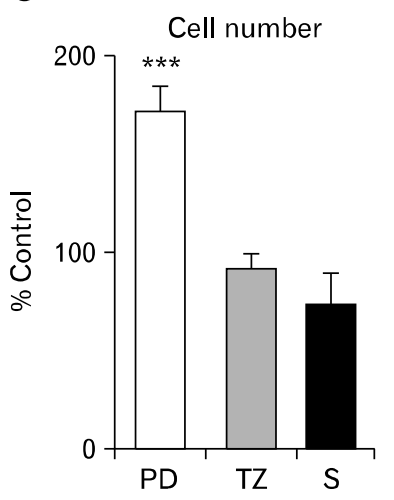

D

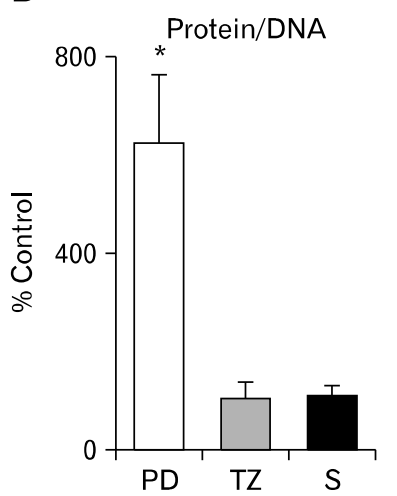

Figure 2. Morphometric characteristics of the smooth muscle layers. (A) H\&E-stained cross-section demonstrating notable hypertrophy in the circular $(\mathrm{cm})$ and longitudinal muscle $(\mathrm{lm})$ layers in a proximal dilated (PD) colon (left panel) as compared with transition zone (TZ, right panel). (B) Cross-sectional muscle thickness (including both circular and longitudinal muscle layers) was significantly increased in the $\mathrm{PD}$ region in comparison with the control. (C, D) Smooth muscle hypertrophy was accompanied by an increase in the myocyte number as estimated by counting the nuclei (C), as well as an increase in myocyte size as measured by the protein-to-DNA content ratio (D) which indicates that the cell phenotype had been changed. $\mathrm{S}$, non-dilated sigmoid colon. ${ }^{*} P<0.05,{ }^{* *} P<0.01,{ }^{* * *} P<$ 0.001 . 
A
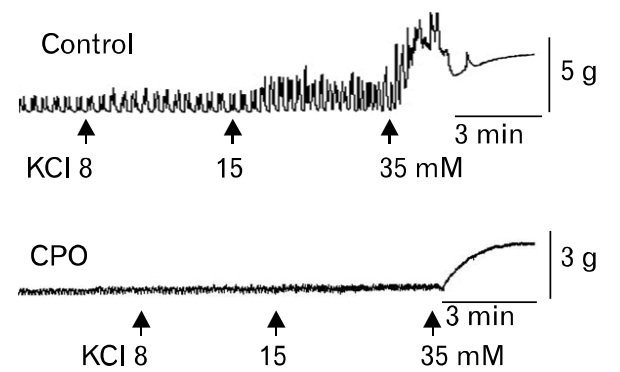

C

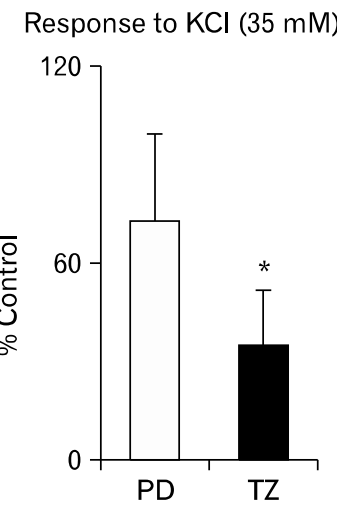

B

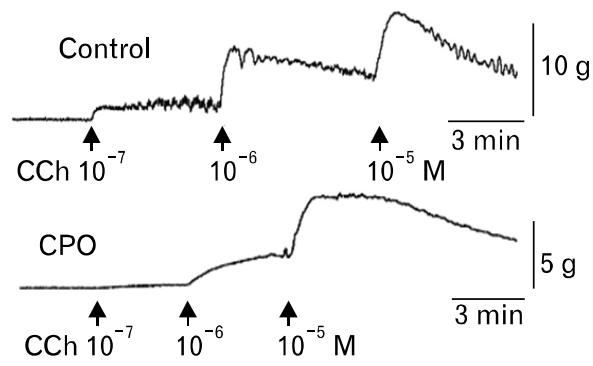

D

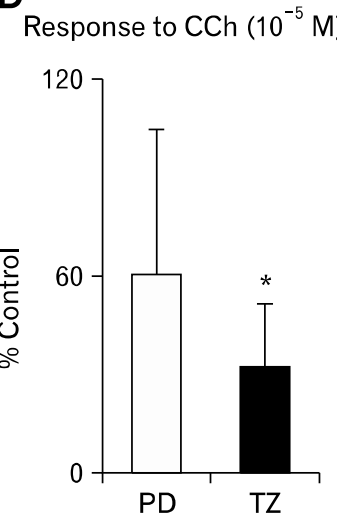

Figure 3. Contractile responses of the circular smooth muscle. (A, B) Example traces of contractile activity in the circular muscles from the transition zone (TZ) in comparison with the controls. The muscle responded to depolarization by potassium chloride $(\mathrm{KCl})$ and cholinergic stimulation by carbachol $(\mathrm{CCh})$ in a concentration-dependent manner, by enhancing amplitudes of a spontaneous phasic activity and producing tonic contractions, respectively. (C, D) In the colonic pseudo-obstruction $(\mathrm{CPO})$ colons, the circular muscles from the $\mathrm{TZ}$ region responded less to $\mathrm{KCl}$ or $\mathrm{CCh}$ in comparison with the proximal dilated (PD) region or region-matched controls. ${ }^{*} P<0.05$. descending colon, which has been previously referred to as the transition zone (TZ; Fig. 1A) $)^{6-10}$ due to its location between the dilated and distal non-dilated loops. The external diameter of the TZ region was on average approximately $70 \%$ of the control $(P$ $<0.01$, Fig. 1B).

In the dilated PD region, smooth muscle hypertrophy was apparent. On H\&E-stained tissues (Fig. 2A), cross-sectional muscle thickness (including both circular and longitudinal muscle layers) increased by 3.4 times compared with the control $(P$ $<0.01$, Fig. 2B). The extent of hypertrophy was greater in the longitudinal muscle layer in comparison with the circular muscle layer. Hypertrophic growth was less marked as distance increased in the oral direction from the $\mathrm{TZ}$ region, ie, ascending colon (data not shown). The cross-sectional muscle thickness in the $\mathrm{TZ}$ region was not statistically different from the control (Fig. 2B). The internal diameter of the lumen in the PD region was estimated by subtracting the doubled cross sectional muscle thickness from the external diameter measured (see above). The result indicates that the internal diameter of the lumen was also increased in the PD region by 2.2 times compared with the control (data not shown). The internal diameter of the lumen estimated in the $\mathrm{TZ}$ region tended to decrease, although the averaged value was not statistically significant as compared with the control.
Smooth muscle hypertrophy in the PD region was through both myocyte hyperplasia and hypertrophy, as reflected by the increase in the number of nuclei (Fig. 2C) and protein-to-DNA content ratio (Fig. 2D), respectively. Cell density estimated by the number of cells per $100 \mu \mathrm{m}$ cross-section of the circular muscle layer was decreased in the PD region to approximately $61 \%$ of the control ( 2.5 vs 4.1 cells per $100 \mu \mathrm{m}, P<0.001$ ), which probably was the result of the increase in myocyte size. The cell density in the circumferential direction of the circular muscle layer in the PD region decreased to approximately $77 \%$ of the control (1.8 vs 2.6 cells per $100 \mu \mathrm{m}, P<0.05$ ) but without significantly changing the total cell number, therefore the smooth muscle cells probably have been stretched circumferentially in the PD region. In contrast to the PD region, the number and size of myocytes on the $\mathrm{TZ}$ cross-section were similar to those of the controls (Fig. $2 \mathrm{C}$ and 2D).

\section{Functional Analysis}

A set of functional, molecular and immunohistochemical studies were performed in series on the colons obtained from 5 CPO patients (No. 1-5 in Table 1). Immediately after surgery, smooth muscle function was evaluated by measuring the contractile responses of circular muscle isolated from different sec- 
A

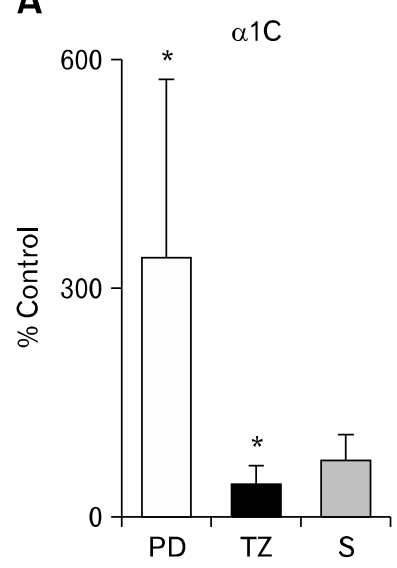

C

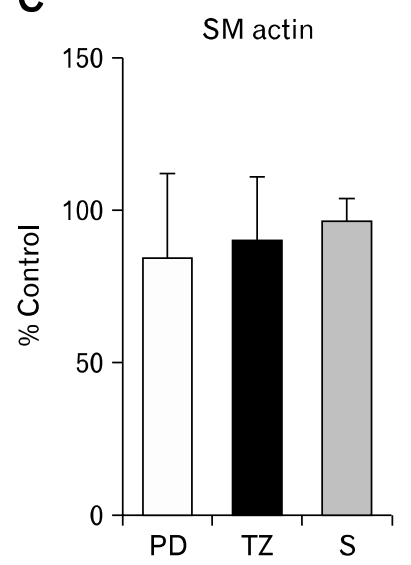

B

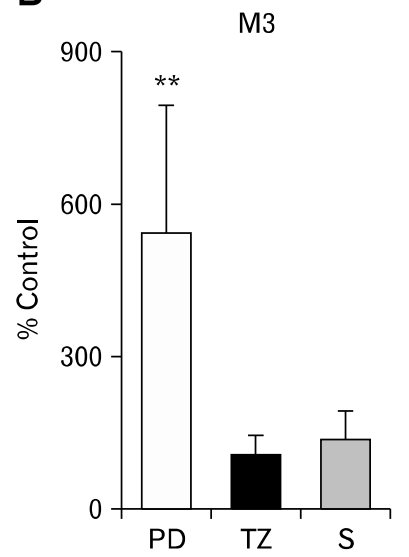

D

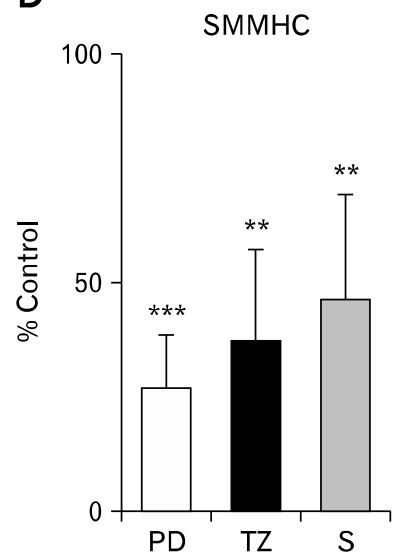

Figure 4. Expression levels of smooth muscle genes. (A) The expression of $\mathrm{L}$-type $\mathrm{Ca}^{2+}$ channel $\alpha_{1} \mathrm{C}$ (pore subunit) mRNA was markedly downregulated in the transition zone (TZ) but upregulated in the proximal dilated (PD) region of the colonic pseudo-obstruction colon. (B) The expression level of muscarinic type 3 (M3) receptor mRNA in the $\mathrm{TZ}$ region was not significantly different from the control, whereas it was upregulated in the PD region. (C) The expression of smooth muscle (SM) alpha actin mRNA was not significantly altered in the CPO colons. (D) The mRNA expression of smooth muscle myosin heavy chain (SMMHC) SM2 isoform was significantly downregulated in the $\mathrm{CPO}$ colons. S, non-dilated sigmoid colon. ${ }^{*} P<0.05$, ${ }^{* *} P<$ $0.01,{ }^{* *} P<0.001$.

tions of the colon, to membrane depolarization induced pharmacologically by $\mathrm{KCl}$ and to cholinergic receptor stimulation by CCh (Fig. 3). In the controls, the circular smooth muscles exhibited various frequencies of spontaneous phasic contractions (3-5 contractions/minute), and the amplitudes were enhanced by increasing the concentrations of $\mathrm{KCl}$ or $\mathrm{CCh}$ (Fig. 3A and 3B, upper traces). In the CPO colons (Fig. 3A and 3B, lower traces), amplitudes of spontaneous phasic activity was significantly decreased such that spontaneous activity was virtually absent unless

amplifier gain was substantially increased. The circular muscles from the $\mathrm{TZ}$ region were significantly less responsive to depolarization by $\mathrm{KCl}$ ( $<35 \%$ of the control) and to stimulation of cholinergic receptor by $\mathrm{CCh}$ (approximately 10 times less sensitive). The responses of the circular muscles from the $\mathrm{PD}$ region to $\mathrm{KCl}$ and $\mathrm{CCh}$ were relatively variable between colons and the average values were not significantly different from the controls (Fig. 3C and 3D).

\section{Molecular Analysis}

The lack of response of the $\mathrm{CPO}$ colons to $\mathrm{KCl}$-induced depolarization and cholinergic receptor stimulation suggests an abnormality possibly at a fundamental level of muscle contraction mechanism. Therefore, we examined the expression levels of the genes that encode L-type $\mathrm{Ca}^{2+}$ channel $\left(\alpha_{1} \mathrm{C}\right.$ pore subunit) and muscarinic M3 receptor proteins, since they are critically involved in smooth muscle responses to depolarization and cholinergic stimuation. The $\alpha_{1} \mathrm{C}$ mRNA was significantly downregulated in the $\mathrm{TZ}$ but upregulated in the $\mathrm{PD}$ region as compared with the controls (Fig. 4A). The expression level of muscarinic $\mathrm{M} 3$ receptor $\mathrm{mRNA}$ in the $\mathrm{TZ}$ region was not significantly different from the control while it was upregulated in the $\mathrm{PD}$ region (Fig. 4B). The $\mathrm{PD}$ and $\mathrm{TZ}$ regions were further examined for the expression levels of the genes encoding smooth muscle contractile proteins, thin filament element SMAA and thick filament forming SMMHC (SM2 iosform in particular). SMAA mRNA expression was unaltered throughout the colonic regions (Fig. 4C), whereas a significant reduction in SMMHC mRNA expression was observed in the CPO colons (Fig. 4D). No distinct regional pattern was resolvable in SMMHC mRNA expression between the $\mathrm{PD}$ and $\mathrm{TZ}$ regions.

\section{Distribution of Enteric Neurons and Interstitial Cells of Cajal}

Distribution of ICC immunoreactivity was varied in that some colons were relatively densely distributed (Fig. 5A), while others exhibited weaker immunoreactivity with some disrupted network (Fig. 5B). No clear regional differences were observed.

Relative to the controls, fewer ganglion cells were observed throughout the $\mathrm{CPO}$ colons. Loss of ganglion cells was most profound in the TZ region (4 vs 55 cells $/ \mathrm{cm}$, TZ vs control, $P<$ $0.001)$, but less severe at sites both orally ( 15 vs 4 cells $/ \mathrm{cm}, P D$ vs TZ, $P<0.001$ ) and aborally (21 vs 4 cells/cm, non-dilated sigmoid colon vs TZ, $P<0.001$ ) to the TZ (Fig. 6). Furthermore, the distribution densities of the inhibitory (eg, nNOS and VIP) 
A

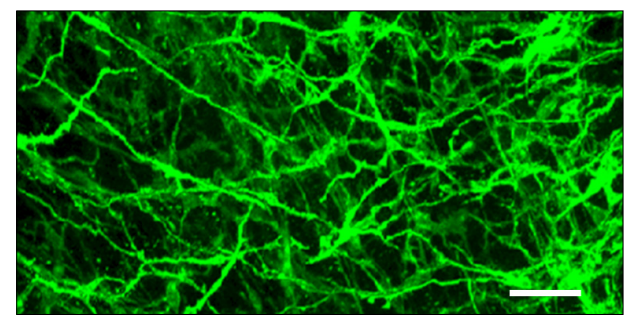

B

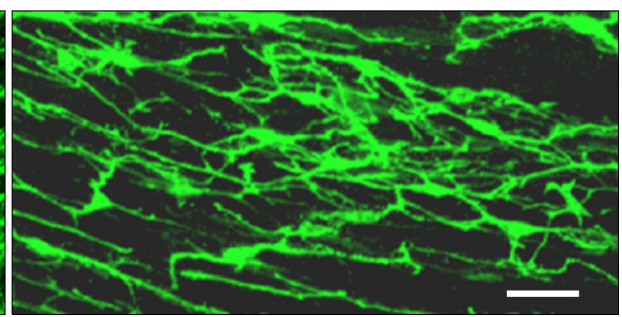

Figure 5. Distribution of interstitial cells of Cajal immunoreactivity was varied in that some colonic pseudo-obstruction colons were relatively densely distributed (A), while others exhibited weaker immunoreactivity with some disruped network (B). No clear regional differences were observed. Scale bar, $40 \mu \mathrm{m}$.
A

\begin{tabular}{cccc}
\hline & \multicolumn{3}{c}{ Ganglion cell number $(\mathrm{cm})$} \\
\cline { 2 - 4 } Patient No. & $\begin{array}{c}\text { Proximal } \\
\text { dilated (PD) }\end{array}$ & TZ & $\begin{array}{c}\text { Non-dilated } \\
(\text { S) }\end{array}$ \\
\hline 1 & 14 & 3 & 32.3 \\
2 & 23 & 8 & 32 \\
3 & 13.4 & 8.1 & 10.0 \\
4 & 18.6 & 3.0 & 28.4 \\
5 & 27.5 & 9 & 21.0 \\
6 & 7 & 2 & 17 \\
7 & 18.5 & 1 & 23 \\
8 & 12 & 5 & 11 \\
9 & 6.8 & 1 & 4.8 \\
10 & 21.7 & 5.5 & 32.5 \\
11 & 12.5 & 3.0 & 16.7 \\
12 & 15 & 4.8 & 30 \\
13 & 7.2 & 3.0 & 12.4 \\
\hline
\end{tabular}

B

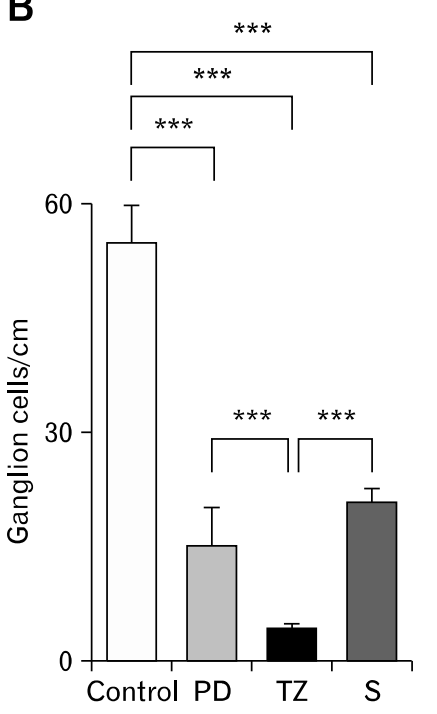

Figure 6. Distribution of ganglion cell. (A) Number of ganglion cells counted in different regions of each colonic pseudoobstruction colon. (B) Summary of the results shown in (A). The transition zone (TZ) retained significantly fewer ganglion cells relative to the control and other areas in the vicinity. PD, proximal dilation; S, non-dilated sigmoid colon. ${ }^{* * *} P<0.001$. and excitatory (eg, vAChT and SP) neurons were evaluated by staining with specific antibodies. There was a significant decrease in nNOS positive (nNOS + ) cells in the CPO colons particularly in the TZ region relative to the control (39 vs 150 cells $/ \mathrm{mm}^{2}, P$ $<0.05$; Fig. 7). This loss was less severe at locations further away from this region (eg, the PD region and ascending colon). The distribution of nNOS + cells was relatively dense aboral to the $\mathrm{TZ}$ region in the $\mathrm{CPO}$ colons (as shown by " $\mathrm{S}$ " in Fig. 7). In contrast, the distribution densities of $\mathrm{VIP}+, \mathrm{vAChT}+$, and $\mathrm{SP}+$ cells were qualitatively similar to the controls, and no notable regional pattern was observed (data not shown).

\section{Discussion}

We have studied colons obtained from patients with medically intractable constipation that was associated with CPO (see patient description in Methods and Results). Thorough comparisons of the morphological, functional and molecular properties of different regions and with region-matched controls revealed that these colons had defects in the smooth muscle and enteric neurons with ICC being relatively less affected. These defects were particularly intense in the segment near the distal end of the dilated region, which may be the principal site of functional obstruction impeding propulsion of the fecal contents, leading to proximal distension. These neuromuscular abnormalities probably synergistically contributed to the extremely suppressed motility observed in the CPO.

Despite the fact that smooth muscle contraction is fundamental to GI motility, few studies have evaluated smooth muscle alterations and their relation to CIPO. ${ }^{16}$ We demonstrate that the smooth muscles from all $13 \mathrm{CPO}$ colons had been functionally and molecularly altered, while their standard histopathologies were not qualitatively different from the controls except marked hypertrophy in the muscle layers (Fig. 2A). Signs of myopathy including smooth muscle degeneration were visually unnoticeable in the histopathology. Thus, conventional histopathological phenotyping alone seems to incompletely characterize the smooth muscle in the CPO colons and may underestimate its pathogenic 
A
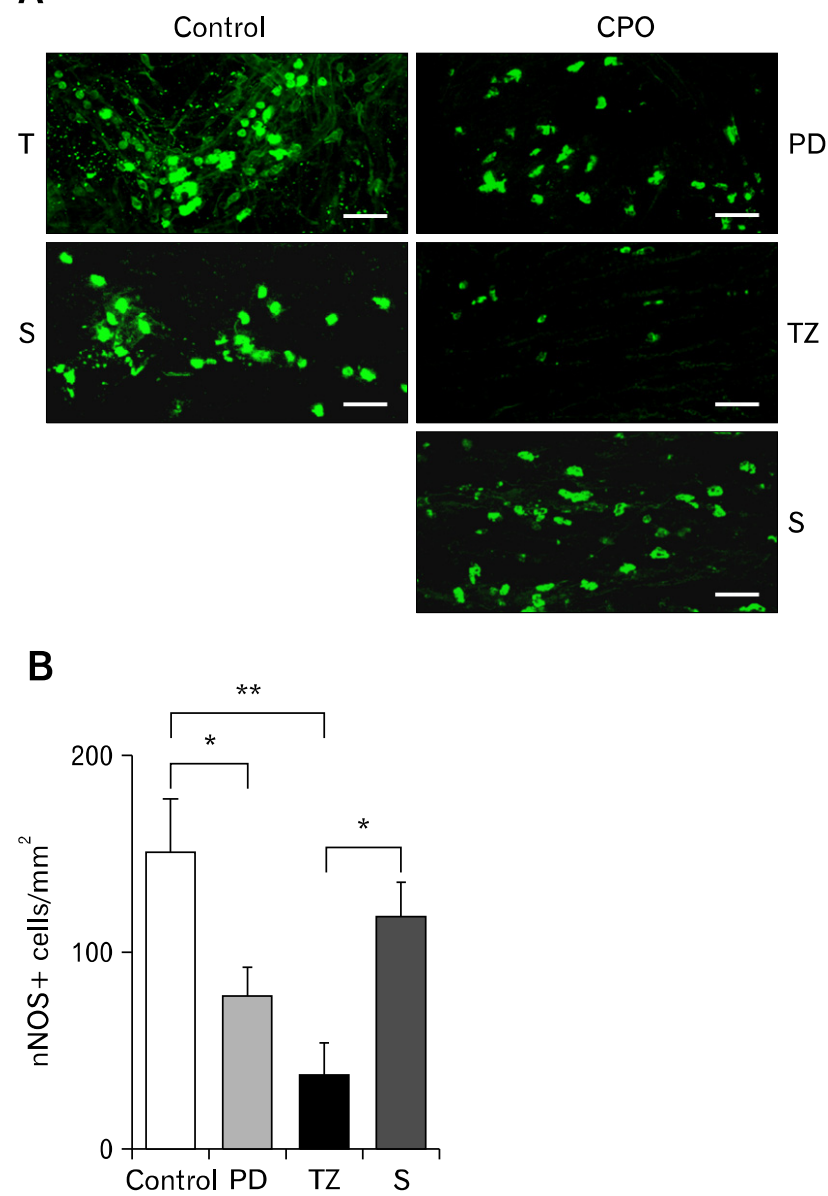

Figure 7. Distribution of neuronal nitric oxide synthase positive (nNOS+) immunoreactivity. (A) nNOS + cells were fewer in the transition zone (TZ) of the colonic pseudo-obstruction (CPO) colons, which appeared to be relatively dense aboral to the $\mathrm{TZ}$ region. (B) Comparison of nNOS + cell counts between different regions indicates that loss of nNOS + cells was less severe at locations further away from the $\mathrm{TZ}$ region. $\mathrm{PD}$, proximal dilation; $\mathrm{T}$, transverse colon; $\mathrm{S}$, non-dilated sigmoid colon. Scale bar $40 \mu \mathrm{m} .{ }^{*} P<0.05,{ }^{* *} P<0.01$.

\section{involvement.}

Smooth muscle abnormalities can be evaluated by assessing the immunoreactivity of the thin filament contractile protein SMAA, according to the London classification and International Working Group guideline, ${ }^{17}$ which was supported by studies on CIPO. ${ }^{18}$ However, SMAA reduction in CIPO appears to be controversial. ${ }^{18-20}$ While Knowls et al ${ }^{18}$ showed 28 of 115 CIPO cases had abnormalities of SMAA immunostaining in circular muscle of the jejunum, Stanghellini et $\mathrm{al}^{19}$ and Gamba et $\mathrm{al}^{20}$ found no differences compared to controls in 11 and 3 CIPO cases, respectively. In our study SMAA expression was evaluated molecularly (Fig. 4) and found to be homogeneously expressed in the controls and unaltered in the CPO colons (Fig. 4C). In contrast, the thick filament forming SMMHC mRNA was significantly reduced in the $\mathrm{CPO}$ colons (Fig. 4D). Hence primary defect may lie in myosin filament. In laboratory animals, ${ }^{21,22}$ SMMHC expression has been one of the most sensitive and specific moleuclar markers for phenotypic alteration in smooth muscle cells and associated with dysfunction in a variety of pathological conditions. ${ }^{23-26}$ Likewise, in the human, SMMHC may also be a sensitive and reliable marker for smooth muscle cell alteration. ${ }^{27,28}$ Interestingly, the reduction in SMMHC mRNA expression was not significantly different between the PD and $\mathrm{TZ}$ regions (eg, $\mathrm{PD}$ vs TZ regions; Fig. 4D). Thus, this alteration in smooth muscle possibly pre-existed. What causes proximal distension in the CPO colon is unknown. We hypothesize that the $\mathrm{TZ}$ region might play a critical role, based on the findings that this region exhibited distinct properties compared to other regions. Circular muscle from the $\mathrm{TZ}$ region was least functional (Fig. 3) with a downregulated expression of an L-type $\mathrm{Ca}^{2+}$ channel gene (Fig. 4A) that would be critical to muscle contractility. The $\mathrm{TZ}$ region also appears to be a focal point for neural deficiencies with decreasing severity the further from the $\mathrm{TZ}$ (Fig. 6 and 7). Extensive luminal dilation with smooth muscle hypertrophy developed proximally to the $\mathrm{TZ}$ region closely resembles the results of partial occlusion mechanically induced in laboratory animals, ${ }^{29,30}$ which lead us to speculate that the $\mathrm{TZ}$ is the site of high resistance due to functional obstruction. Accumulation of the fecal contents proximally may result in passive stretch and luminal dilation, leading to smooth muscle hypertrophy as an adaptation to increased functional demand. The TZ region was not extensively evaluated in previously reported studies on GI motility disorders involving luminal distension, and further exploration is warranted.

In the human colon NO is released basally as a major inhibitory neurotransmitter and its pharmacological inhibition depolarizes and contracts smooth muscle cells near the myenteric plexus. ${ }^{31}$ In neuronal nitric oxide synthase (nNOS) knock-out mice, the colon is more constricted than wild type. ${ }^{32}$ Hence, mild luminal narrowing of the $\mathrm{TZ}$ region (Fig. 1) may be a product of the persistent tonic contraction of the circular muscle due to local reductions in NO release. There were no significant changes in cell number or cell size (Fig. 2), despite a slight decrease in the diameter of the $\mathrm{TZ}$ region, which is consistent with this hypothesis. The pathophysiological impact of this subtle luminal narrowing is unclear. The length of the $\mathrm{TZ}$ region varied among 
the colons but was approximately $4 \mathrm{~cm}$ on average, which might be sufficient to produce the effect of functional obstruction in the area. ${ }^{33}$ More importantly, NO is associated with peristalsis and mediates the descending relaxation reflex in the mouse colon, ${ }^{34,35}$ and the nNOS-knock out mice showed reduced velocity of pellet propulsion. ${ }^{32}$ Thus, prominent local reductions in nNOS+ cells might result in bolus transfer difficulties through the region. A deficiency in nNOS neurons has been noted in other GI motility disorders like achalasia in the esophagus, where nNOS is characteristically deficient with the loss of myenteric ganglion cells in the lower esophageal sphincter. ${ }^{36}$ No obvious change in ICC was observed in early achalasia despite a segmental loss of nitrergic nerves with aperistalsis, ${ }^{37}$ which may be also applicable to our cases. How NOS neurons are selectively lost is unclear. Intriguingly, the TZ region is often located close to the "watershed area" that is considered vulnerable to ischemia. ${ }^{38}$ Local ischemia-reperfusion selectively damages NOS neurons in laboratory animals, ${ }^{39}$ which could also occur in the human. Whether the decrease in nNOS immunoreactivity described here was due to the actual degeneration of nNOS+ neurons or if the level of nNOS expression was reduced requires further study.

It is unlikely that the cases presented here are a variant of adult (or continuous from childhood) Hirschsprung's disease (HD) or long segment HD, which is supported by several clinicopathologic characteristics different from those known for HD in that (1) no aganglionosis was detected in the $\mathrm{TZ}$ region and other areas throughout the colon, (2) the recto-sigmoid region was functionally normal (RAIR was clearly present), (3) no mutation in the genes associated with HD was observed, ${ }^{9}$ and (4) the expression level of acetylcholine esterase did not increase ${ }^{40}$ (data not shown).

One limitation of our study is that the age of the control group was not exactly matched to the CPO group ( $58 \pm 13$ vs 36 \pm 7 years, respectively), mainly because the prevalence of colon cancer is relatively low in young ages. Despite the age difference, cross-sectional muscle thickness in the ascending colon was similar between the two groups (data not shown), and SMAA expression was also not different (Fig. 4C). In addition, the basal contractile activity of the circular muscle in the control group was comparable to another study on young patients, ${ }^{41}$ suggesting that this age discrepancy might not have significantly influenced the results.

In summary, this study describes region-specific alterations in smooth muscle and enteric nerves in the colon isolated from patients with colonic pseudo-obstruction. These alterations could result in functional obstruction in the $\mathrm{TZ}$ area which cause the distension of the proximal colon and smooth muscle hypertrophy and in which partial nNOS depletion could play a key role.

\section{References}

1. Dudley HA, Sinclair IS, McLaren IF, Mcnair TJ, Newsam JE. Intestinal pseudo-obstruction. JR Coll Surg Edinb 1958;3:206-217.

2. Stanghellini V, Cogliandro RF, De Giorgio R, et al. Natural history of intestinal failure induced by chronic idiopathic intestinal pseudo-obstruction. Transplant Proc 2010;42:15-18.

3. Byrne WJ, Cipel L, Euler AR, Halpin TC, Ament ME. Chronic idiopathic intestinal pseudo-obstruction syndrome in children - clinical characteristics and prognosis. J Pediatr 1977;90:585-589.

4. Cogliandro RF, De Giorgio R, Barbara G, et al. Chronic intestinal pseudo-obstruction. Best Pract Res Clin Gastroenterol 2007;21:657669.

5. Mann SD, Debinski HS, Kamm MA. Clinical characteristics of chronic idiopathic intestinal pseudo-obstruction in adults. Gut 1997; 41:675-681.

6. Choi JS, Lim JS, Kim H, et al. Colonic pseudoobstruction: CT findings. AJR Am J Roentgenol 2008;190:1521-1526.

7. Lee BH, Kim N, Kang SB, et al. Two cases of chronic idiopathic intestinal pseudo-obstruction with different clinical features. J Neurogastroenterol Motil 2010;16:83-89.

8. Choe EK, Park SH, Park KJ. Colonic pseudo-obstruction with distinct transitional zone in adult constipation patients: pathological analysis and results of surgical treatment. Am Surg 2011;77:736-742.

9. Do MY, Myung SJ, Park HJ, et al. Novel classification and pathogenetic analysis of hypoganglionosis and adult-onset Hirschsprung's disease. Dig Dis Sci 2011;56:1818-1827.

10. Han EC, Oh HK, Ha HK, et al. Favorable surgical treatment outcomes for chronic constipation with features of colonic pseudo-obstruction. World J Gastroenterol 2012;18:4441-4446.

11. Masaki T, Sugihara K, Nakajima A, Muto T. Nationwide survey on adult type chronic intestinal pseudo-obstruction in surgical institutions in Japan. Surg Today 2012;42:264-271.

12. Webster C, Dayton M. Results after colectomy for colonic inertia: a sixteen-year experience. Am J Surg 2001;182:639-644.

13. Sohn G, Yu CS, Kim CW, et al. Surgical outcomes after total colectomy with ileorectal anastomosis in patients with medically intractable slow transit constipation. J Korean Soc Coloproctol 2011;27:180-187.

14. Miyazaki K, Torashima Y, Mochizuki S, et al. Hand-assisted laparoscopic subtotal colectomy with cecorectal anastomosis for chronic idiopathic colonic pseudo-obstruction: report of a case. Surg Today 2014;44:581-585.

15. Livak KJ, Schmittgen TD. Analysis of relative gene expression data using real-time quantitative $\mathrm{PCR}$ and the 2(-Delta Delta $\mathrm{C}_{\mathrm{T}}$ ) Method. Methods 2001;25:402-408.

16. Knowles CH, Farrugia G. Gastrointestinal neuromuscular pathology in chronic constipation. Best Pract Res Clin Gastroenterol 2011;25: 43-57.

17. Knowles CH, De Giorgio R, Kapur RP, et al. The London Classification of gastrointestinal neuromuscular pathology: report on behalf of the Gastro 2009 International Working Group. Gut 2010; 
59:882-887.

18. Knowles CH, Silk DB, Darzi A, et al. Deranged smooth muscle $\alpha$-actin as a biomarker of intestinal pseudo-obstruction: a controlled multinational case series. Gut 2004;53:1583-1589.

19. Stanghellini V, Cogliandro RF, De Giorgio R, et al. Natural history of chronic idiopathic intestinal pseudo-obstruction in adults: a single center study. Clin Gastroenterol Hepatol 2005;3:449-458.

20. Gamba E, Carr NJ, Bateman AC. Deficient alpha smooth muscle actin expression as a cause of intestinal pseudo-obstruction: fact or fiction? J Clin Pathol 2004;57:1168-1171.

21. Burkhard FC, Lemack GE, Zimmern PE, Lin VK, McConnell JD. Contractile protein expression in bladder smooth muscle is a marker of phenotypic modulation after outlet obstruction in the rabbit model. J Urol 2001;165:963-967.

22. Austin JC, Chacko SK, DiSanto M, Canning DA, Zderic SA. A male murine model of partial bladder outlet obstruction reveals changes in detrusor morphology, contractility and myosin isoform expression. J Urol 2004;172(4 Pt 1):1524-1528.

23. Löofgren M, Fagher K, Wede OK, Arner A. Decreased shortening velocity and altered myosin isoforms in guinea-pig hypertrophic intestinal smooth muscle. J Physiol 2002;544(Pt 3):707-714.

24. Martin AF, Bhatti S, Pyne-Geithman GJ, et al. Expression and function of $\mathrm{COOH}$-terminal myosin heavy chain isoforms in mouse smooth muscle. Am J Physiol Cell Physiol 2007;293:C238-C245.

25. Chi M, Zhou Y, Vedamoorthyrao S, Babu GJ, Periasamy M. Ablation of smooth muscle myosin heavy chain SM2 increases smooth muscle contraction and results in postnatal death in mice. Proc Natl Acad Sci USA 2008;105:18614-18618.

26. Chi M, Zhou Y, Sopariwala D, Periasamy M. SM+/- male mice are predisposed to develop urinary tract obstruction and hyper contractility of the bladder smooth muscle upon ageing. J Smooth Muscle Res 2011;48:67-78.

27. Aikawa M, Sivam PN, Kuro-o M, et al. Human smooth muscle myosin heavy chain isoforms as molecular markers for vascular development and atherosclerosis. Circ Res 1993;73:1000-1012.

28. Wedel T, Van Eys GJ, Waltregny D, Glénisson W, Castronovo V, Vanderwinden JM. Novel smooth muscle markers reveal abnormalities of the intestinal musculature in severe colorectal motility disorders. Nuerogatroenterol Motil 2006;18:526-538.

29. Chang IY, Glasgow NJ, Takayama I, Horiguchi K, Sanders KM, Ward SM. Loss of interstitial cells of Cajal and development of elec- trical dysfunction in murine small bowel obstruction. J Physiol 2001; 536(Pt 2):555-568.

30. Chen J, Chen H, Sanders KM, Perrino BA. Regulation of SRF/CArG-dependent gene transcription during chronic partial obstruction of murine small intestine. Neurogastroenterol Motil 2008; 20:829-842.

31. Keef KD, Murray DC, Sanders KM, Smith TK. Basal release of nitric oxide induces an oscillatory motor pattern in canine colon. J Physiol 1997;499(Pt 3):773-786.

32. Dickson EJ, Heredia DJ, McCann CJ, Hennig GW, Smith TK. The mechanisms underlying the generation of the colonic migrating motor complex in both wild-type and nNOS knockout mice. Am J Physiol Gastrointest Liver Physiol 2010;298:G222-G232.

33. Kim HJ, Kim AY, Lee CW, et al. Hirschsprung disease and hypoganglionosis in adults: radiologic findings and differentiation. Radiology 2008;247:428-434.

34. Spencer NJ, Smith TK. Simultaneous intracellular recordings from longitudinal and circular muscle during the peristaltic reflex in guinea-pig distal colon. J Physiol 2001;533:787-799.

35. Smith TK, Spencer NJ, Hennig GW, Dickson EJ. Recent advances in enteric neurobiology: mechanosensitive interneurons. Neurogastroenterol Motil 2007;19:869-878.

36. Kraichely RE, Farrugia G. Achalasia: physiology and etiopathogenesis. Dis Esophagus 2006;19: 213-223.

37. Chen J-H, Wang X-Y, Liu LW, et al. On the origin of rhythmic contractile activity of the esophagus in early achalasia, a clinical case study. Front Neurosci. 2013;7:77.

38. Meyers MA. Griffiths' point: critical anastomosis at the splenic flexure. Significance in ischemia of the colon. AJR Am J Roentgenol 1976;126:77-94.

39. Rivera LR, Thacker M, Pontell L, Cho HJ, Furness JB. Deleterious effects of intestinal ischemia/reperfusion injury in the mouse enteric nervous system are associated with protein nitrosylation. Cell Tissue Res 2011; 344:111-123.

40. Budianto IR, Obata S, Kinoshita Y, et al. Reevaluation of acetylcholinesterase staining for the diagnosis of Hirschsprung's disease and allied disorders. J Pediatr Gastroenterol Nutr 2015;60:606-612.

41. Rae MG, Fleming N, McGregor DB, Sanders KM, Keef KD. Control of motility patterns in the human colonic circular muscle layer by pacemaker activity. J Physiol 1998;510(Pt 1):309-320. 